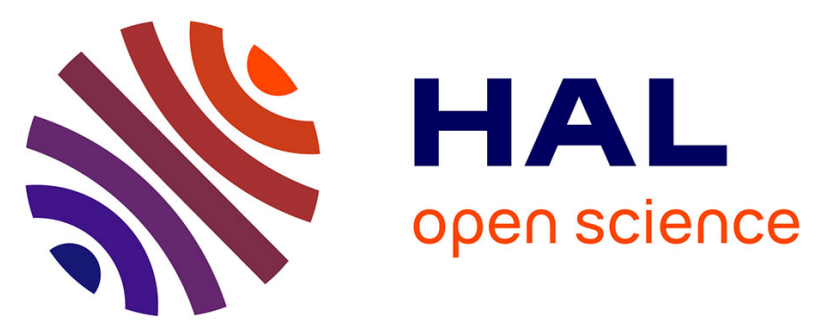

\title{
MANAGING DISRUPTIVE TECHNOLOGIES LIFE CYCLE BY EXTERNALIZING THE RESEARCH. SOCIAL NETWORK AND CORPORATE VENTURING IN THE SILICON VALLEY
}

Michel Ferrary

\section{To cite this version:}

Michel Ferrary. MANAGING DISRUPTIVE TECHNOLOGIES LIFE CYCLE BY EXTERNALIZING THE RESEARCH. SOCIAL NETWORK AND CORPORATE VENTURING IN THE SILICON VALLEY. International Journal of Technology Management, 2003, 25 (1-2), pp.165-180. 10.1504/IJTM.2003.003096 . hal-03233534

HAL Id: hal-03233534

https://hal.science/hal-03233534

Submitted on 24 May 2021

HAL is a multi-disciplinary open access archive for the deposit and dissemination of scientific research documents, whether they are published or not. The documents may come from teaching and research institutions in France or abroad, or from public or private research centers.
L'archive ouverte pluridisciplinaire HAL, est destinée au dépôt et à la diffusion de documents scientifiques de niveau recherche, publiés ou non, émanant des établissements d'enseignement et de recherche français ou étrangers, des laboratoires publics ou privés. 
MANAging DisRuptive TeChNOLOGIES LIFE CYCLE BY EXTERNALIZING THE RESEARCH.

Social Network AND CORPorate Venturing in THE Silicon VALLEY

International Journal of Technology Management, Vol. 25, $n^{\circ} 1 / 2,2003$

Michel Ferrary, Ceram Sophia-Antipolis

Email: Michel.Ferrary@ceram.fr

\begin{abstract}
The capability to generate and develop disruptive technologies drives the market in the high-tech sector. Traditional strategic theory recommends internalisation of R\&D to keep a competitive advantage. The Silicon Valley example points out that the most successful high-tech companies (Cisco Systems, Intel, Sun,...) externalise their researches by doing corporate venturing. These companies manage their portfolio of technologies by acquiring small businesses that have developed disruptive technologies. This kind of acquisitive strategy needs specific organisational and managerial practices to embed the large company in the industrial-network structure of the Silicon Valley. Thus, managers of innovation have to get a large social capital to gather information inside business networks.
\end{abstract}

Keywords: Corporate venturing, Silicon Valley, Social networks, Acquisitive strategy, $\mathrm{R} \& \mathrm{D}$ externalisation 


\section{Introduction}

Porter [1] observes that technology is among the most prominent factors that determine the rules of competition. In the high tech industry, technological advantages can be sustained when competitors cannot duplicate the technology or when the firm innovates faster than competitors. According to many strategic management scholars, the pace of technological innovation drives the competitive edge in the high-tech sector [2].

The strategic dimension of $R \& D$ has led large corporations in the high-tech sector to internalise the entire process of technological innovation (i.e. Research activities, Development activities, Product-Process development activities and Market development activities). This strategic dimension of internalisation is specific to the high-tech sector, "while many firms outsource some of their technology through licensing arrangements, $R \& D$ with other firms, consortia, strategic alliances, joint ventures, and acquisitions, high-technology firms must source the bulk of their new technology internally through investments in $R \& D^{\prime \prime}[3]$.

Given this understanding in the literature, how do companies keep up with the pace of radical innovation in a fast-moving industry with internal R\&D? What is a successful technological innovation in the high-tech sector? Is the internal research the best way for generating disruptive technologies? Is there a market for research products and how to use it? Could the externalisation of research be an efficient strategy in the high-tech sector? What kinds of capabilities does a large corporation need when it 
externalises its research? Why is the embeddedness of the firm in its business environment a strategic issue?

I argue that in the high-tech sector, technological innovation is one of the most important forces affecting a firm's competitive position but the internalisation of research is not the best way to produce disruptive technologies. The competitiveness of a company depends on its ability to find on the market the right technology and to develop it internally or by cross-fertilisation with other technologies held by the company.

Contingency theorists [4] argue that the more complex and unstable the firm environment is, the more decentralised the firm's decision making process needs to be. According to Powell [5], from the viewpoint of firms, the externalisation is the most decentralised system of governance because individual behaviour is not dictated by supervising agent, no organ of system-wide governance or control is necessary. Markets are a form of noncoercive organisation, they have coordinating but not integrative effects. As Hayek [6] suggested, market coordination is the result of human actions but not of human design. Many scholars in economic sociology [7], have shown the impact of the quality of the social bond that the economic agent has with members of its socioeconomic environment to explain the success of his actions. Granovetter [8], with the concept of "embeddedness", has studied the impact of the social networks held by individuals or underlain by communities to explain their economic success (research of job, development of the American electrical system,...). Research in economic sociology has found that social networks often provide ways to circumvent the economic regulation of the market. The ties among members in a network reduce the information asymmetry for trades made between them. The collective phenomenon of the social network can also 
be interpreted from an individual level perspective with the concept of "social capital" [9]. Each individual holds social capital that corresponds to the whole of resources that his durable social relationships offer. In this case, the concept of social capital suggests that social relationships of an individual constitutes an advantage in his economic activity because social ties he has reduce the moral hazard in trades made with others in the network.

By influencing the extent to which firms have access to information about potential partners, social networks can alter the opportunities firms perceive for viable alliances. Thus, the externalisation of research means increases the importance of embbededness of the firm in its business network.

In the high-tech sector, a part of the uncertainty is linked to the emergence of disruptive technologies (i.e. radical innovation in contrast with incremental innovation [10]). I argue that the most efficient way for large corporations to manage disruptive technologies is to buy a start-up with such technologies rather than to invest a lot of money in the R\&D division to develop them. Competition to create new markets through disruptive technologies does not happen between internal $\mathrm{R} \& \mathrm{D}$ division of large companies but between their acquisitive strategies. Admitting that externalisation of research by buying new technologies is more efficient than internalisation by getting large labs has consequences in the management practices. With internalisation, the issue for the firm is to hire the best scientific researchers. With externalisation, the issue is to be well connected with small innovative businesses. In this case, the efficiency of the technology management depends on the social capital of the people in charge. 
This research is based on a qualitative analysis of technology management done by large high-tech companies from the Silicon Valley. I have conducted field interviews with several economics actors from the Silicon Valley (executives in large high-tech companies, venture capitalists and entrepreneurs). Following economic historians [11], I have done an historical comparison between two companies: Lucent Technologies (exATT) and Cisco Systems in order to highlight the different level of efficiency between internalisation and externalisation of technology management.

In this paper, I analyse how the adherence to the traditional management of innovation led why large high-tech companies to miss technological breakthroughs. I analyse how large high-tech companies like Sun, Cisco, Novel, Intel, Nokia, Siemens, Alcatel, and so forth externalise implicitly part of their research by buying start-ups and their technologies. I compare the technology management of the two most important companies in the communication equipment sector: Lucent and Cisco. I analyse how these companies do corporate venturing by using venture capital activities to monitor technological innovation on the market and to have more flexibility than a traditional firms where R\&D activities are internalised. Finally, I examine if corporate venturing practices are an efficient means to penetrate the regional network-based industrial system of the Silicon Valley.

\section{Consequences of the traditional management of innovation}

\section{The traditional pattern of technology management}

According to the classical strategic management analysis, there are two main motivations for companies to internalise the research investments. Firstly, many companies prefer to 
internalise their research investment in order to protect their competitive advantage. Through patents, inventions and discoveries sometimes allow their originators to establish a potential for economic rents. The sustainability of the rent depends on the pace of the diffusion of an innovation. Some factors that slow down the rate of diffusion are patenting of the firm's technology and related technology, secrecy, in-house development of prototypes and production equipment, vertical integration into key parts that embody or give clues to the technology and personnel policies that retain employees. Technological leaders are also often vertically integrated, building or modifying equipment in-house to protect technology, and are discrete in public disclosures. It is striking how many of the firms known to be secretive are also technological leaders [12]. Successful technological leaders pay close attention to their stock of R\&D skills. They avoid cutting back R\&D staff in industry downturns or profit squeezes. They also seek out relationships with the leading scientific centres in appropriate fields, and attempt to develop an image as the best place to work for the types of research personnel that support their technology strategy.

Secondly, the strategic management literature argues that the firm is more efficient than the market to co-ordinate resources and competencies in order to generate innovation from laboratory to market. The difficulties with transferring technology across market interface are three kinds: recognition, disclosure and team organisation [13]. The competitive edge that large corporation often have is their managerial capability to coordinate resources to generate new technology. For the scholars in this field, the internal co-ordination of resources is more efficient than the external combination through the market. Innovations require resources, so acquisition of resources constitutes a major 
theme in entrepreneurship [14]. Internal projects of innovation have access to an uncommon resource: the core competencies that have developed in the organisation [15]. Connecting projects with the organisation's unique competencies can give them a competitive advantage [16], provide powerful capabilities in technology and design [17], and enhance an innovation's speed to market. In many high-tech markets in which product technologies are rapidly evolving, manufacturing process innovation is becoming an increasingly critical capability for product innovation. Companies that have treated process development as an integral part of product development are supposed to have accrued tremendous advantages. Connecting a new technology with competencies also enhances the organisation's ongoing adaptation, since the linkage improves overall innovation management [18], enables the firm to reconfigure its resources, and provides a way to experiment with new ideas [19]. In the long run, competitiveness derives from an ability to build the core competencies at lower cost and more speed than competitors, than spawn unanticipated products. The real sources of advantage are to be found in management's ability to consolidate corporate-wide technologies and production skills into competencies that empower individual business to adapt quickly to changing opportunities [20].

According to this strategic model, large high-tech corporations created important internal laboratories (Watson Labs for IBM, Xerox PARC for Xerox, Labs Bells for ATT, CNET for France Telecom,...) for two reasons: protecting competitive edge and higher efficiency of internal management of R\&D. Nevertheless an historical analysis of the high-tech industry point out that for each disruptive technology a new range of companies underlying its growth and champions of the previous technology are not those 
of the new. For example, leaders of the minicomputer technology like DEC, Data General, Burroughs, Wang, NCR, Honeywell or Prime are not those of the PC era which is dominated by Compaq, Dell or Apple. Also, the major actors of the Internet era (Aol, Sun, Yahoo,...) do not come from the PC sector.

Several large high-tech companies have missed technological breakthroughs in their fields. Moreover, there are some examples where some researchers found the technology but it has been rejected by the top management of the company. IBM is a good illustration. This firm is the world's largest corporation research organisation with $\$ 5,5$ billion research division with 2,900 scientists around the world (including five Nobel laureates). Even with its huge investments in research, IBM has missed all the technological breakthroughs of the IT sector. Worst, sometimes they have developed the technology in their laboratories but did not believe in its market opportunity [21].

The Xerox PARC is also a good example [22]. By the 1970s, the Xerox's president, charged PARC with providing the technology Xerox needed to become "an architect of information" in the office. By the mid-1970s, the centre created the Alto, an expensive machine with some of the attributes of a personal computer, which was supposed to serve as a research prototype. Alto and its software became popular inside Xerox that PARC installed a couple of thousand of the systems. Product development, however, was managed by another Xerox group, which was championing a rival machine called the Star, later to reach the market as Xerox's 8010 workstation. More recently, the failure of Interval, an incubator backed by Paul Allen (co-founder of Microsoft), points out difficulties of the planning and internalisation of research to produce marketable disruptive technologies. 
Factors of failure to produce marketable disruptive technologies

I argue that there are five reasons for the inability of large corporations to produce disruptive technologies:

1. Strategic myopia. The CEO and the board of directors do not believe in the opportunity of the new technology because they are more focused on optimisation of economies of scales. Blinded by their initial successes, they failed to recognise the limits of a business model that presumed stability in an environment of technological and market volatility. For example, the minicomputer makers organised themselves on the assumption of stable markets and technologies. They adopted autarkic structures that supported their high-volume manufacturing strategies: they sought to stabilise demand by locking their customers into proprietary technologies, and they built centralised organisations to co-ordinate the complex process of mass producing computer system.

2. Concurrent technology. The top management might reject a new technology because it competes with the current portfolio of the firm. In this case, it is difficult for the venture to secure access to important capabilities. For example, DEC's research lab in Silicon Valley developed state-of-the art RISC and Unix Technologies in the early 1980s, but its discoveries ware virtually ignored by headquarters, which continues to favour the highly profitable VAX-VMS system[23].

3. Scientific focalisation. Researchers are more focused on the scientific dimension than on the market needs. Traditional industrial labs had been developed to shield research organisations from day-to-day business pressures so that research could 
focus on creating or discovering important technological concepts. The developers did not work closely with customers to find out if these "neat" features were actually desired. The criteria for success regarding inventions and discoveries are technical rather than commercial. Corporate scientists expect their work to be evaluated primarily on the quality of the investigation rather than the commercial usefulness of its results. For example, in its communication, Lucent Technologies is more proud that Bell labs "went from less than one patent a day to three patents a day within the first calendar day" (Annual report) than revenues generated by their technologies.

4. Organisational Barrier. Managing the interface between corporate research and development is difficult because of the different orientations and expectations of the groups involved. Top management has tried to take advantage of the inside initiatives that often emerged based on technologies developed in corporate research by, for example, creating a separate new venture division. But, Burgelman, Maidique and Wheelwright [24] have documented serious problems associated with the new venture division design.

5. Low incentive. The incentive for researchers to find marketable and disruptive technologies is very little. The compensation system in large corporations does not reward real innovations. Large companies do not give their researchers the opportunity to become wealthy by inventing a disruptive technology inside the company.

Moreover there is an increasing number of high-tech industries that outsource manufacturing completely to third-party contractors or joint-venture partners. In so doing, 
those companies hope to avoid the risks of investing in expensive manufacturing plants and losing sight of what they see as their true source of advantage: product R\&D [25].

\section{A new pattern for acquisitive strategy: the corporate venturing}

\section{The nature of the corporate venturing}

The term corporate venturing refers to a large corporation that take minority equity in young, unlisted companies that have substantial growth prospects [26]. Corporate venturing should not be confused with the typical venture capital investment; it does not primarily focus on direct financial return. Companies typically make venture-capital investments for two strategic reasons. The first is to provide advance warning of key technological and market developments that might affect their own businesses. Direct involvement with small businesses gives a company's executives a much better understanding of what is going on in the entrepreneurial undergrowth that can not be obtained from reading reports and attending conferences. The second reason for corporate venturing is to provide specific opportunities for commercial relationships with the company it invested in (through OEM deals, licensing, joint ventures or research contracts). This can sometimes greatly shorten product development times and provide access to expertise the investor does not have.

A large number of disruptive technologies have been nurtured in the Silicon Valley and the venture capital industry is well developed in this region. In 1999, about $38 \%$ of all venture capital funding in the US come from big companies, signalling a change in strategic management of technologies. The list of large high-tech companies converted to corporate venturing is large: Microsoft, Sun, Novel, IBM, ATT, Alcatel... 
The most famous one is Intel. By 1999, Intel's total portfolio of investments was valued at roughly $\$ 4.8$ billion and contained about 300 companies worldwide. Just in 1999, Intel created its Intel 64 fund to invest in new technologies that will eventually use more Intel next-generation 64-bit chips and formed a \$250 million equity fund to invest in new voice and data communications technology companies. As Intel is now focused on networking, a key element was the acquisition by 1999 of network chipmaker Level One Communications for more than \$2billion in stock. This led to Intel's new networking effort, dubbed Internet Exchange Architecture (IXA), which features reprogrammable chips for switches and routers. To support IXA, Intel created a new venture capital fund, the \$200 million Intel Communications Fund. The first investment Intel made out of this fund was in Trillium Digital Systems. Trillium, which produces communications software, will optimise its products for IXA.

In 1998, Lucent Technologies has formed a venture capital fund to invest in new technologies and the company's chairman steps down to head the unit. Lucent Venture Partners has been funded with $\$ 100$ million and seeks investments in emerging technologies such as data networking, semiconductors, and communication software. These investments would either mesh with the research at Bell Labs or would fill some holes in the company's strategy. Lucent Venture Partners will leverage external investments into Lucent Technologies' existing operations through the formation of joint marketing agreements, joint product development efforts, and possibly partnerships and acquisitions. The group will be closely aligned with Lucent Technologies' corporate strategies and operations. 
Now, even high-tech companies based outside Silicon Valley create venture capital funds there to find new technologies. In 1999, Microsoft has invested over \$9 billion in more than 70 start-up. In 1998, Nokia established the Nokia Venture Capital Fund, capitalised at \$100 million to fuel future growth and boost new product and longterm business development. Nokia VCF has invested in two Silicon Valley-based companies: Ipsilon, which has now been integrated into Nokia Telecom's IP Routing, and Diamond Lane. By 1999, Siemens has launched an US-based strategic venture operation as part of the company's Corporate Research Group. The group began making investments in venture funds whose portfolios contained companies related to Siemens' business interests. By 2000, Alcatel has created a $\$ 150$ million investment fund for the same purpose.

\section{The drivers of the highest efficiency of acquisitive strategy}

By doing corporate venturing, large companies gain access to business plans seen by venture capital firms, have contact with start-ups, have access to financing at preferred rates in later rounds, and block direct competitors from similar privileges. Corporatesponsored venture capital funds are motivated by a desire of corporation to gain "windows on innovation". In addition, there are several other possible motives including acquisition opportunities in strategic areas; defensive tactics to identify competitive threats; cross-fertilising skills by interfacing entrepreneurs with company managers, etc. Internal expansion through a company's own $R \& D$ efforts is difficult too. $R \& D$ in new fields is very expensive, and fresh ideas often get mired in bureaucratic conventionality and the need to concentrate on existing product lines. Indirect corporate venture capital 
investing - as opposed to direct involvement - has become the more effective method for corporations to achieve their primary goals without struggling with the people and compensation problems of an "in-house" operation.

In addition, many observers believe that smaller venture companies spawned by industrial giants can be more innovative than larger more bureaucratic in-house operations. They point out that more than half of all inventions and innovations introduced since World War II originated in small companies. A National Science Foundation study of the period between 1953 and 1973 concluded that small firms produced four times as many innovations per research and development dollar as medium-sized firms, and 24 times as many as the largest firms [27].

Several recent studies on Silicon Valley emphasise the role of the venture capital firms in nurturing and developing new technologies. Hellman and Puri [28] find that the presence of a venture capitalist is associated with a significant reduction in the time taken to bring a product to market, especially for innovators. Venture capitalists are extensively involved in the businesses they finance, not only closely monitoring their activities, but also providing valuable support and governance. Venture capital firms provide advice and consulting services with the senior management ranging from helping to raise additional funds, reviewing and assisting with strategic planning, recruitment of financial and human resource management, introduction of potential customers and suppliers, public relations and legal specialists. The relationships between venture capital firms and entrepreneurs are a kind of governance of innovation by tournament [29]. A venture capital might stop the funding of a start-up if it does not believe in the competitiveness of the technology, market or management team. This flexibility is impossible in an R\&D 
division of a large corporation. Venture capital firms view each funding decisions not as a project approval but as an option on future decisions. They reduce their exposure by investing in small increments until the key risk factors are resolved. Cutting losses on failing ventures can make a big difference to overall returns. Abandoning ventures in this way has never been easy for large corporations, whose projects are often underpinned by personal relationships, political concerns, and vague strategic objectives. In addition, many companies make funding decisions as part of an annual budgeting cycle rather than in accordance with project-specific deadline. Venture capitalists gain their experience through years of apprenticeship, and have a strong incentive to make impartial decisions. On the other hand, corporate managers rarely bring such relevant experience to bear, and may find it difficult to ignore the broader political context of their decisions. Venture capital firms share several attributes with the start-ups they fund. They tend to be small, flexible, and quick to make decisions: even major investments can be concluded in a few weeks, sometimes even days. They have flat hierarchies and they rely heavily on equity and other incentive pay. Corporate managers usually operate in a more traditional setting. Decisions can take months, especially if large sums are involved.

Most venture capital firms boast expertise in managing start-up risk and growing new companies, but readily admit their inexperience when it comes to adding value to mature businesses. In contrast, corporate managers usually do possess the skills to manage a venture that has reached maturity. Venture capital firms and large high-tech companies complement each other in the managing of the life cycle of disruptive technologies. The real core competence of large high-tech companies is to find outside disruptive technologies and develop them inside. The example of the Silicon Valley 
challenges the idea that a sustainable competitive edge in high-tech sector depends on huge investments undertaken by an internal Research Division.

The pattern of the research externalisation in the American communication equipment sector: Lucent Technologies versus Cisco Systems

In the early of the 1980s, AT\&T was the major actor in the American equipment communication business. In 1990, when Cisco Systems (a communication equipment company created in 1984) became public, its net revenues were $\$ 69.7$ million, its $R \& D$ budget was $6.1 \$$ million, and the R\&D department employed 53 persons. By 1990, ATT's revenues were $\$ 43.7$ billion ( $\$ 6.7$ billion in telecommunications network systems), its R\&D budget was $\$ 2.4$ billion with more than 24000 persons in Bell Laboratories. At the beginning of the year 2000, Cisco has become a major actor of the American equipment communication business. Lucent (a spin-off of ATT in 1996), despite its huge research investments in Bell Labs has lost its technological leadership. In 1999, Cisco's revenues are $\$ 12$ billion and the company employs 23492 workers. Lucent's revenues are $\$ 38.3$ billion; the company employs 153000 workers (24000 in the Bell Labs) and the $\$ 4.7$ billion R\&D budget. The higher capitalisation of Cisco Systems ( $\$ 310$ billion against $\$ 236$ billion for Lucent by the beginning of 2000) reveals how financial analysts seem to prefer its strategy. The primary goal of this section is to understand why ATT has lost its technological leadership and how Cisco has built its competitive edge. Secondly, I will examine how Lucent Technologies is evolving from an internalised research model to an externalised one. 
ATT has been unable to generate a market disruptive technologies and was the archetype of the firm having all factors inducing incapability to create disruptive technologies. For decades, the business that is now Lucent Technologies had been the maker of phone equipment for ATT. It included the vaunted Bell Laboratories and its Nobel prize-winning technology. But a history of supplying the country's phone monopoly made Lucent a bureaucratised organisation with an $R \& D$ division focused on incremental innovation. Lucent's engineers emphasised reliability instead of disruptive innovation (strategic myopia). They often spent years developing products and tended to work more on what they wanted than on customers' needs (scientific focalisation and low incentive). By the 1970s, from a technological and competitive point of view, the communication equipment sector was stable and only marked by incremental innovation. Since the 1980s, the communications industry is experiencing rapid changes in the technologies. Traditional circuit-based switching and data packet transmission are converging. The migration to an universal network increases the competition to provide the equipment, software and services that will serve as the infrastructure of this universal network. In 1998, Bill O'hea, president of Lucent's communications group admits "Quite frankly, we missed the last generation of data networking while a part of ATT. We had all the technology to compete, but it was buried under a huge organisation" [30](concurrent technology and organisational barrier).

Secondly, the externalisation of the research done by Cisco Systems through an acquisitive strategy has been more efficient in creating a competitive portfolio of technologies. The markets for the communication equipment products are characterised by rapidly changing technology, evolving industry standards, frequent new product 
introductions, and evolving methods of building and operating networks. There can be no assurance that any $\mathrm{R} \& \mathrm{D}$ division will successfully identify new product opportunities, and develop and bring new products to market in a timely manner. So, when Cisco Systems is unable to enter a particular market in a timely manner, with internally developed products, licensing technology from other businesses or acquiring other businesses are better alternatives than internal R\&D. One of the ways Cisco Systems has addressed the need to develop new products is through acquisitions of other companies. Cisco has grown at a blistering pace by making 45 acquisitions in five years (18 in 1999). In a sector marked by a high uncertainty on technologies, an acquisitive strategy is more reactive and flexible than the internal $\mathrm{R} \& \mathrm{D}$ division.

Cisco dominates the US market of data networking equipment with $55 \%$ share, vs. Lucent's has only $2 \%$. Currently $80 \%$ of all Internet traffic passes through a Cisco router before reaching its final destination. By 1998, Cisco had only $2 \%$ of the telecommunications equipment market. Furthermore, Cisco has expanded its products line, particularly in the area of optical technology. This expansion has been done through an acquisitive strategy. On August 1999, Cisco acquired privately-held Monterey Networks, an innovator of infrastructure-class, optical cross-connect technology used to increase network capacity at the core of an optical network. On September 1999, Cisco acquired privately-held Cocom A/S, a leading European developer of high-speed Internet access solutions over cable, satellite and wireless networks based on international standards. In November 1999, Cisco paid \$7 billion to acquire Cerent, a maker of a particular kind of optical gear that connects synchronous optical network rings, which carry regional phone traffic, to Cisco Routers. Despite the acquisitions of two optical- 
based systems companies Cerent and Monterey Networks, Cisco has lacked technology that can zip voice and data traffic across vast distances. Such equipment is important for national communications providers such as Qwest Communications International, MCI WorldCom or ATT. By December 1999, Cisco had purchased the optical-based network equipment assets of European giant Pirelli for about $\$ 2,15$ billion in stock. The move fills a hole in Cisco's portfolio of technologies. Management of innovation through an acquisitive strategy is the major feature of Cisco Systems. Its successes influences its competitors and illustrate the generalisation of a new pattern of management of innovation.

By 1998, the change in Lucent's technology management from a strictly internal R\&D strategy to an acquisitive strategy points out the new framework of technology management in the high-tech sector. Despite this huge R\&D capability, Lucent uses the same means as Cisco: buying start-ups to improve its technology portfolio. In 1996, Lucent bought only one company (Agile Networks) and three in 1997 (Triple C, Octel and Livingston). After, the pace of acquisitions has accelerated and Lucent has bought 11 companies in 1998 and 17 in 1999. On the growing market for corporate networking equipment, Lucent favours an acquisitive strategy. Lucent has periodically bought data networking companies such as Prominet et Xedia to complete its enterprise portfolio. Lucent also bought Ascend, the top maker of phone switches that use a technology called asynchronous transfer mode (ATM). But over time, carriers were eager to move beyond ATM to a technology called Internet protocol (IP). The problem for Lucent is that Cisco holds $67 \%$ of the IP market. Then, Lucent has acquired IP companies, such as Juniper Networks and Nexabit Networks and, by November 1999, Lucent Technologies 
announced that ATT is among 60 phone companies that plan to test a piece of super-fast Internet gear Lucent acquired by purchasing Nexabit Network.

As part of the process of analysing each of these acquisitions, Lucent Technologies made a decision to buy technology that had not yet been commercialised rather than develop the technology internally. Lucent based this decision on factors such as the amount of time it would take to bring the technology to market by inventing it inside. However, the externalisation of research by an acquisitive strategy raises specific managerial issues.

\section{The managerial issues of the research externalisation}

The requirements to penetrate the network-based industrial system of Silicon Valley

The fundamental proposition of social network theory is that network ties provide access to resources and to information [31]. However, social relations, often established for other purposes, constitute information channels that reduce the amount of time and investment required for gathering information. The role of networks is to provide an efficient information-screening and distribution process for members of those networks.

Several scholars emphasize that the Silicon Valley is a network-based industrial system [32]. According to Saxenian [33]: "Silicon Valley has a regional network-based industrial system that promotes collective learning and flexible adjustment among specialist producers of a complex of related technologies. The region's dense social networks and open labor markets encourage experimentation and entrepreneurship". These networks are not formal networks between companies linked by contract or mutual shareholding. They are underlain by interpersonal links. Business networks are 
determined by individual networks. The informal socializing that grew out of these quasifamilial relationships supported the ubiquitous practices of collaboration and sharing of information among local producers. These informal conversations were pervasive and served as an important source of up-to-date information about competitors, customers, markets, and technologies. Entrepreneurs came to see social relationships and even gossip as a crucial aspect of their businesses. In an industry characterized by rapid technological change and intense competition, such informal communication was often of more value than more conventional but less timely forums such as industry journals. Local engineers recognize that the quality of the feedback and information obtained through their networks depends upon the credibility and trustworthiness of the information provider. This sort of quality is only assured with individuals with whom you share common backgrounds and work experiences. A variety of more and less formal gatherings - from trade association, meetings and industry conferences to trade shows and hobbyists' clubs also served as specialized forums for information exchange. These trade shows effectively compress social and professional networks in time and space and provide opportunities for informal exchange.

The conditions for the existence of exchanges among a social network are different from pure arm's-length relationships or formalised relationships inside an organisation. To obtain the disruptive technologies produced by the network-based industrial system of the Silicon Valley, the large companies have to be involved in exchanges inside these networks. There are three conditions for large companies to enter in the network-based industrial system of the Silicon Valley and nurture a complex and dialectical process in 
which social capital is created and sustained through exchange and in which, in turn, social capital facilitates exchanges.

1. The physical proximity. Geographic proximity allowed firms to monitor emerging technologies and avoid being caught off guard by unanticipated breakthroughs. Geographic proximity promotes the repeated interaction and mutual trust needed to sustain collaboration and to speed the continual recombination of technology and skill. The physical proximity between people is a very important factor in building social network. The proximity allows frequent formal and informal meetings that are a means for gathering information on all members of social networks. The need of physical proximity explains why all large high-tech companies set up their corporate venturing entity in Silicon Valley. For example, Lucent Venture Partners for Lucent Technologies, Nokia Venture for Nokia, Innovacom for France Telecom, Siemens Mustang Ventures for Siemens or ATT Ventures are located -or have an office- in the Silicon Valley.

2. The social capital of the decision-maker. The success of the corporate venturing is linked to the quality of the cross-fertilisation between large company's divisions (R\&D, marketing, sales, business units...) and the start-up it invested in. An efficient corporate venturing depends on the overlap of internal and external social networks. This overlap allows the cross-fertilisation between start-ups owning disruptive technologies and internal capabilities of development owned by the large company. It would be easier for a large company to penetrate the network-based industrial system of the Silicon Valley by employing people involved in its networks. The social capital of people in charge of the corporate venturing is more important than their intellectual 
capital. In internal R\&D, the Human Resource Management issue is to recruit the best researchers. In external $R \& D$ through corporate venturing, the Human Resource Management issue is to recruit people having or/and able to build social network to gather technological opportunities before competition. The higher his social capital is, the better the venture capitalist will be involved in the social network and more efficient will be the corporate venturing. For example, the vice-president in charge of the acquisitive strategy for Sun Microsystems (J.B. Schwartz) define his job "as broken down into four principal responsibilities. First, and foremost is planning for Sun. Second is competitive strategy, once we know where we are going, we need to know how to get there. The third is just general industry awareness and relationships. Industry awareness tells you who can help, both from a partnership perspective, as well as a potential acquisition or investment perspective. Ultimately, that creates the need for the fourth element of the organisation, which is the transactions and the integration responsibility for actually running the deals, buying the companies, making the investments, as well as ensuring that they are successfully integrated inside of Sun" [34]. As former co-founder and CEO of Lighthouse Design, a start-up bought by Sun, and as former vice-president of the Sun venture capital group, J.B. Schwartz gets a large inside and outside social capital which is very useful to manage an acquisitive strategy. He occupies his position because of his technical expertise and his social capital.

3. Give resources that the decision-maker can exchange. It is necessary to bring to the network a specific resource to be accepted by its members. By doing corporate venturing, large companies potentially bring funding to start-ups and also 
technological support (for example the Intel 64 Fund has already made a number of investments, mostly in companies developing software for use with the ITanium chip and gives them an access to the technology almost one year before to ship it on the market) and commercial opportunities. The key is for persons in charge of the corporate venturing to be real decision-makers to implement this potential crossfertilisation.

The organisational structure of the corporate venturing has an influence on the building and the efficiency of the networks

Considering these three needed features (proximity, median-actor between internal and external network, marketable resources), the key is to find the best structure for doing corporate venturing. The issue is to find managerial practices that improve the embeddedness of the firm and the connections between internal and external social networks. The acquisitive strategy becomes more efficient than internal research to get new technologies in the high-tech sector. So more and more large high-tech companies buy start-ups to expand their portfolio of technologies. The increasing demand entails higher price for start-ups (Lucent paid \$20 billion for Ascend and Cisco paid \$7 billion for Cerent). Due to this inflation, large companies change the arbitrage between maturity and risk when they acquire a start-up. The entry cost increases with the life cycle of the new technology. The risk underlying a new technology depends on its maturity. The maturer a technology developed by a start-up is, the lesser risk a large company takes by acquiring it. On the other hand, the maturer the new technology is, the higher is the price of the start-up that owns it. So, now large high-tech companies try to hook new 
technologies earlier in their life cycle by becoming a shareholder of start-ups in first stages of their development. Rather than to buy expansive mature technology, large companies spread out their investments among fledgling businesses with very new technologies by taking a minority in the start-up equity. These investments are riskier but their prices are lower. The company accepts that some of these investments could be lost but it will buy the total equity of start-ups if they develop an interesting technology. This technology management practice is known as corporate venturing. There are three organisational ways for doing it [35]:

1. Internal corporate venturing. The large company gives the responsibility to its Department of Finance or to its Department of Strategy to make these investments in start-ups (Microsoft, Nortel, Intel, General Electric). Advantages are that the team in charge of investments has a clear vision of the technology strategy of the company and it has strong social networks inside with the mother company. This proximity can be too close and lead to a strategic myopia. Others disadvantages are that the decision making process is too slow to follow the pace of decision in the world of start-ups. The inside decision-makers do not have a strong social network among the network-based industrial system of the Silicon Valley (entrepreneurs, lawyers, VCs, universities,...) so he misses technological opportunities because they are not connected with the right social network of information. By keeping the corporate venturing unit inside the firm that could be difficult to implement incentive managerial device like stock-options.

2. External corporate venturing. The large company can create a fund and give its management to a traditional venture capital firm (ex: The Java Fund of Sun that is 
run by Kleiner, Perkins, Caufield and Byers). Advantages are that the traditional venture capitalist has very good social network in the Silicon Valley for gathering a lot of technological opportunities and he is very flexible in his decision-making process. Disadvantages are that traditional venture capitalists tend to lack a clear vision of the technology strategy of the large company and are more focused on the profitability than on the potential transferability of the investment. They do not have a social network inside the company to handle the cross-fertilisation.

3. Mixed corporate venturing. The large company creates and funds its own venture capital firm with partners coming from the mother company and partners coming from the network-based industrial system of the Silicon Valley. For example, among the five partners of Lucent Venture Partner, three of them used to work for Lucent Technologies and the two others were previously CEO of Silicon Valley start-ups which have been bought by Lucent Technologies. Among the eight partners of ATT Ventures, six come from ATT, one from one of the most famous venture capital firm of the Silicon Valley and the last one from the Californian office of a consulting group. Moreover, the two partners coming from outside are also graduates of Stanford University. Advantages of this form of corporate venturing are that the venture capitalists are independent from the mother company (they monitor the decision-making process) and they can work with all traditional venture capitalists of the Silicon Valley (Kleiner and Perkins, Sequoia Capital, Mayfied Fund, etc) which are interested in working with a large high-tech company because it gets money and can build technical and commercial capabilities to leverage the start-up innovations. Moreover, partners coming from Mother Company have a lot of connections inside 
Lucent Technologies and they increase the opportunities of cross-fertilisation. The partners coming from the network-based industrial system are connected to many actors in the Silicon Valley which enable them to find technological opportunities.

The competitive advantage for large companies of the high-tech sector is determined by the quality of their relationships with the network-based industrial system of the Silicon Valley. The organisational design of corporate venturing has an influence on the sustainability of the competitive advantage. I suggest that differences between firms, including differences in performance, may represent differences in their ability to create and exploit social capital. In the last few years many large high-tech companies chose the third structure (mixed corporate venturing): Deutsche Telecom, Sun, IBM, Siemens, Nokia, France Telecom, Alcatel, Samsung, etc. It seems that this organisational design is the most efficient way to penetrate the network-based industrial system of the Silicon Valley.

\section{Conclusion}

The new pattern of management of innovation used by large high-tech companies in Silicon Valley has strong implications for organisational theory. Firstly, it validates the contingency theory for which a higher level of uncertainty induces a decentralisation of the decision-making process. The research externalisation through and acquisitive strategy squares with the extreme form of decentralisation. The decision-making process is more efficient in the framework of a externalised research. Secondly, it questions the strategic theory by pointing out that the research internalisation is not the best way to assure a competitive edge by securing disruptive technologies. A research internalisation 
fails to generate marketable disruptive technologies because of five reasons: strategic myopia, reject of concurrent technology, scientific focalisation, organisational barrier and low incentive. The research externalisation enables companies to overcome these problems.

However the research externalisation raises new managerial and organisational issues. From a managerial point of view, the issue is no longer having the best scientific people but people able to detect quickly new disruptive technologies produced by small businesses and favour their integration in the Mother Company. Thus, the social capital and the embeddeness in business environment of managers of innovation become a critical issue. The large high-tech companies discover information through its interactions with other economics actors of the market, then the social networks in which the firm's employees are embedded drive the quality of information that it gathers. The key to organisational success is to design a governance structure allowing the building of networks and giving incentives to people with social capital so they will use it to implement the corporate strategy. The creation of a venture capital unit employing a mix a people coming from the Mother Company and from the network-based system of Silicon Valley seems to be the right governance structure to detect and to integrate new disruptive technologies.

\section{References}

1. Porter, M (1985) Competitive advantage. Creating and sustaining superior performance, The Free Press, New-York, p. 557.

2. Abell D. (1980) Defining the Business, Prentice-Hall, New-York, p. 293; Friar, J. and Horwitch, M. (1985) 'The emergence of technology strategy: an new dimension of strategic management', Technology in Society, No.7, pp. 143-178; Tushman, M. and Moore, W. (1982) Readings in the Management of Innovation, Pitman Publishing, 
Boston, p. 652; Tushman, M. and O'Reilly III, C. (1997), Winning through innovation : a practical guide to leading organizational change and renewal, Harvard Business School Press, Boston, p. 258.

3. Burgelman, R., Maidique, M. and Wheelwright, S. (1996) p. 493, Strategic Management of technology and innovation, Irwin, Chicago, p. 923.

4. Burns, T. and Stalker, G. (1961) The management of innovation, Tavistock, London, p. 295; Lawrence, P. and Lorsch, J. (1967), Organization and environment, Harvard University Press, Boston, p. 248; Galbraith, J. (1973) Designing Complex Organizations, Addison-Wesley Publishing Company, Reading, p. 150.

5. Powell, W.W. (1990), 'Neither market nor hierarchy: network forms of organization', in Staw, B. and Cummings, L. (eds.), Research in Organizational Behavior, Vol. 12, pp. 295-336, JAI Press, Greenwich.

6. Hayek, F. (1945), 'The use of knowledge in society', American Economic Review, Vol. 35, No. 4, p. 519-530.

7. Leff, N. (1979), 'Entrepreneurship and economic development : The problem revisited', Journal of Economic Literature, March, pp. 46-64; Karpik, L. (1989) 'L'économie de la qualité', Revue Française de Sociologie, Avril-Juin, pp. 187-210; Baker, W. (1990) 'Market networks and corporate behavior', American Journal of Sociology, No. 96, pp. 589-625; Degenne, A. et Forse, M. (1994) Les réseaux sociaux, Armand Colin, Paris, p. 288; Ghoshal, S. et Nahapiet, J. (1998) 'Social capital, intellectual capital and the organizational advantage', Academy of Management Review, Vol. 23, No. 2, pp. 242-266; Gulati, R. (1998) 'Alliances and networks', Strategic Management Journal, Vol. 19, pp. 293-317.

8. Granovetter, M. (1973) 'The strength of weak ties', American Journal of Sociology, No. 78, pp. 1360-1380; Granovetter, M. (1974) Getting a job: a study of contacts and careers, Harvard University Press, Boston, p. 372; Granovetter, M. (1985) 'Economic action and social structure: The problem of embeddedness', American Journal of Sociology, Vol. 91, No. 3, pp. 481-510.

9. Bourdieu, P. (1986) 'The form of capital' in: Richardson J. G. (ed), Handbook of theory and research for the sociology of education, pp. 241-258, Greenwood Press, Wesport, $572 \mathrm{p}$.

10. Burgelman, R., Maidique, M. and Wheelwright, S. (1996) Strategic Management of Technology and Innovation, Irwin, Chicago, p. 923.

11. Chandler, A. D. (1962) Strategy and Structure, MIT Press, Cambridge, p. 874; Pettigrew, A. (1985) The Awakening Giant. Continuity and Change, in: ICI, Blackwell, p. 563.

12. Porter, M. (1985), Competitive advantage. Creating and sustaining superior performance, p. 186, The Free Press, New-York, p. 557.

13. Arrow, K. (1974) The Limits of Organization, Norton, New-York, p. 217; Williamson, O. E. 1975) Markets and hierarchies : Analysis and antitrust implications, The Free Press, New-York, p. 358; Teece, D. J. (1982) 'Economies of scope and the scope of the enterprise', Journal of Economic Behaviour and Organization, Vol. 1, p. 223-247.

14. Starr, J. and McMillan, I. (1990) 'Resource cooptation via social contracting: Resource acquisition strategies for new ventures' Strategic Management Journal, Vol. 11, Special Issue, pp. 79-92. 
15. Penrose E.T., (1959) The Theory of the Growth of the Firm, Wiley, New-York, 341 p.; Wernerfelt, B. (1984) 'A resource-based view of the firm', Strategic Management Journal, Vol. 5, No. 2, pp. 171-180.

16. Barney, J. (1991) 'Firm resources and sustained competitive advantage', Journal of Management, Vol. 17, No. 1, pp. 99-120.

17. Prahalad, C.K. and Hamel, G. (1991) 'The core competence of the corporation' p. 277-299 in: Montgomery, C. and Porter, M. (Eds) Strategy, Harvard Business Review book, p. 475.

18. Dougherty, D. and Heller, T. (1994) 'The illegitimacy of product innovation in large firms, Organization Science, Vol. 5, No. 2, pp. 200-218.

19. Burgelman, R. (1983) 'Corporate entrepreneurship and strategic management: Insights from a process study', Management Science, Vol. 29, No. 12, pp. 1349-1363.

20. Prahalad, C.K. and Hamel, G. (1991) 'The core competence of the corporation', p286, p. 277-299 in: Montgomery, C. and Porter, M. (Eds) Strategy, Harvard Business Review book, p. 475.

21. Saxenian, A. (1994) Regional Advantage, Harvard University Press, Boston, p. 226; Chesbrough, H.W. and Teece, D.J. (1999) 'When is virtual virtuous? Organizing for innovation', pp. 31-54 in: Managing High-Tech Industries', Harvard Business Press, $326 \mathrm{p}$.

22. Cringely, R. (1991) Accidental Empires, Harper Business, New-York, p. 324.

23. Saxenian (1994), Regional Advantage, p. 137, Harvard University Press, Boston, p. 226

24. Burgelman, R., Maidique, M. and Wheelwright, S. (1996) Strategic Management of Technology and Innovation, Irwin, p. 923.

25. Iansiti, M. and West, J. (1999) 'Technology integration: Turning great research into great products', in: Managing High-Tech Industries, Harvard Business Press, p. 1-30.

26. Perez, R. (1986) Inside Venture Capital, Praeger, New-York, p. 189.

27. Silver, A. (1983) The Entrepreneurial Life, Wiley, New-York, p. 244.

28. Hellmann, T. and Puri, M. (1999) 'The interaction between Product Market and Financing Strategy : The role of Venture Capital', Working paper, Stanford University..

29. Aoki, M. (1999) 'Information and Governance in the Silicon Valley Model', Working Paper, Stanford University.

30. 'Lucent Technologies', Redherring, p. 41, August 1998, No. 57.

31. Coleman, J.S. (1988) 'Social capital in the creation of human capital', American Journal of Sociology, Vol. 94, supplement, pp. 95-120.

32. Florida, R. and Kenney, M. (1990) 'Why Silicon Valley and Route 128 won't save us', California Management Review, Vol. 33, pp. 68-88.

33. Saxenian (1994), Regional Advantage, p. 31, Harvard University Press, Boston, p. 226

34. 'Inside Sun Microsystems", San Jose Mercury News, p. 17, June 26 ${ }^{\text {th }}, 2000$.

35. Brody, P. and Erlich, D. (1998) 'Can big companies become successful venture capitalists?' The McKinsey Quarterly, No. 2, pp. 51-63. 
